\title{
PENDAMPINGAN PENYUSUNAN HARGA POKOK PRODUKSI BAGI PELAKU UMKM DI KOTA SEMARANG
}

\author{
Jacobus Widiatmoko', Maria Goreti Kentris Indarti², \\ Elen Puspitasari ${ }^{3}$, Sabas Setyo Hadi ${ }^{4}$ \\ 1,2,3Fakultas Ekonomika dan Bisnis, Universitas Stikubank Semarang, Indonesia \\ ${ }^{4}$ Universitas Indraprasta PGRI Jakarta, Indonesia
}

\begin{abstract}
Abstrak
Kegiatan pengabdian ini memiliki dua tujuan, yaitu (1) memberikan pemahaman kepada para pelaku UMKM di Kota semarang tentang arti pentingnya menghitung harga pokok produksi dan melakukan pencatatan ke dalam jurnal dengan benar, (2) memberi pelatihan dan mendampingi pelaku UMKM agar mampu menghitung harga pokok produksi dengan benar. Berdasarkan komunikasi awal dengan calon mitra diperoleh informasi tentang masalah yang dihadapi pelaku UMKM di Kota semarang yaitu belum dipahaminya manfaat perhitungan harga pokok produksi sehingga mereka umumnya tidak melakukan perhitungan harga pokok produksi. Mereka menetapkan harga jual berdasarkan harga di pasaran, sehingga mereka tidak dapat menghitung berapa laba/rugi sebenarnya dari kegiatan usaha mereka. Solusi yang ditawarkan untuk memecahkan masalah tersebut adalah memberikan pelatihan dan pendampingan dalam perhitungan harga pokok produksi. Metode kegiatan yang digunakan dalam pengabdian ini adalah (1) ceramah untuk menyampaikan konsep perhitungan harga pokok produksi dan pencatatan dalam jurnal dan (2) kasus untuk memberikan contoh praktik menghitung harga pokok produksi, serta (3) melakukan pendampingan di lapangan. Berdasarkan hasil evaluasi terhadap kegiatan, diperoleh informasi tingkat pemahaman peserta terhadap materi yang diberikan sebesar $70 \%$. Selanjutnya Tim pengabdian masih melakukan pendampingan di lapangan selama dua minggu.
\end{abstract}

Kata kunci: pengabdian, pelatihan, pendampingan, harga pokok produksi

\begin{abstract}
This dedication activity has two objectives, namely (1) giving an understanding to the MSMEs in Semarang City about the importance of calculating the cost of production and recording it correctly in journals, (2) providing training and accompanying MSMEs to be able to calculate the basic price production properly. Based on preliminary communication with potential partners, information was obtained about the problems faced by MSMEs in Semarang City that is not yet understood the benefits of calculating the cost of production so that they generally do not calculate the cost of production. They set selling prices based on prices on the market, so they cannot calculate what the actual profit / loss is from their business activities. The solution offered to solve the problem is to provide training and assistance in calculating the cost of production. The method of activities used in this service are (1) lectures to convey the concept of calculating the cost of production and recording in journals and (2) cases to provide examples of practices to calculate the cost of production, and (3) provide assistance in the field. Based on the results of the evaluation of the activities, obtained information on the level of understanding of participants to the material provided by $70 \%$. Furthermore, the service team is still providing assistance in the field for two weeks.
\end{abstract}

Keywords: dedication, training, assistance, cost of production

Correspondence author: Jacobus Widiatmoko,jwidiatmoko@edu.unisbank.ac.id, Semarang, Indonesia 


\section{PENDAHULUAN}

Usaha kecil dan menengah (UKM) di berbagai negara termasuk di Indonesia merupakan salah satu penggerak perekonomian rakyat yang tangguh. Hal ini karena kebanyakan para pengusaha kecil dan menengah berangkat dari industri keluarga atau rumahan (Wiralestari, Firza, \& Mansur, 2018). Dengan demikian, konsumennya pun berasal dari kalangan menengah ke bawah yang jumlahnya relatif besar (Mukhzarudfa \& Kusumastuti, 2019). UMKM memiliki peran yang sangat penting dan strategis dalam menopang pembangunan ekonomi nasional. Peran tersebut antara lain(1) kedudukannya sebagai pemain utama dalam kegiatan ekonomi di berbagai sektor, (2) penyedia lapangan kerja terbesar, (3) pemain penting dalam pengembangan kegiatan ekonomi lokal dan pemberdayaan masyarakat, (4) pencipta pasar baru dan sumber inovasi, serta (5) sumbangannya dalam menjaga neraca pembayaran melalui kegiatan ekspor (UndangUndang, Nomor. 20: 2008).

UMKM telah terbukti mampu berkontribusi secara signifikan dalam memacu pertumbuhan ekonomi, penyediaan lapangan kerja untuk mengurangi angka pengangguran, serta mendistribusikan hasil-hasil pembangunan. Pertumbuhan jumlah UMKM di Indonesia cukup pesat dan mampu menyerap hampir 97,2\% tenaga kerja dari total angkata kerja yang ada. Namun, pesatnya pertumbuhan jumlah UMKM tidak dibarengi dengan tingginya angka penjualan (Sariwaty, Rahmawati, Oktaviani, \& Amran, 2019). Masalah yang sering dihadapi oleh pengusaha UMKM bersifat multidimensi, yang artinya UMKM memiliki banyak permasalahan (Maghfirah \& BZ, 2016). Salah satu masalah mendasar yang dihadapi oleh para pelaku UMKM adalah kurangnya kemampuan dalam bidang akuntansi termasuk melakukan perhitungan harga pokok produksi dengan benar.

Fenomena menunjukkan bahwa masih banyak pelaku UMKM yang belum mampu memperoleh laba secara optimal karena ketidakmampuan mereka dalam menghitung harga pokok produksi secara tepat (Yuliyanti \& Saputra, 2017). Hal ini antara lain disebabkan oleh kurangnya kemampuan pelaku UMKM dalam penggolongan biaya sehingga terdapat beberapa biaya yang tidak diperhitungkan dalam harga pokok, seperti biaya penyusutan dan tenaga kerja yang yang berasal dari pemilik sendiri Hal ini antara lain disebabkan oleh kurangnya kemampuan pelaku UMKM dalam penggolongan biaya sehingga terdapat beberapa biaya yang tidak diperhitungkan dalam harga pokok, seperti biaya penyusutan dan tenaga kerja yang yang berasal dari pemilik sendiri (Nurlela \& Rangkuti, 2017). Selama ini perusahaan hanya menetapkan harga jual sesuai dengan harga pasar tanpa menghitung biaya-biaya yang telah dikeluarkan selama proses produksi sesuai dengan prosedur akuntansi dan kurang terperinci (Prabowo, 2019).

Harga pokok (biaya) produksi merupakan biaya yang diperlukan untuk memproses suatu produk. Biaya produksi terdiri atas biaya bahan, tenaga kerja dan overhead (Setiadi, Saerang, \& Runtu, 2014; Widyastuti \& Mita, 2018). Terdapat beberapa manfaat bila perusahaan mengetahui harga pokok setiap produk yang dihasilkan, yaitu (1) menentukan harga jual (Macpal, Morasa, \& Tirayoh, 2014), (2) memantau realisasi biaya, (3) menghitung laba rugi, dan (4) menghitung harga pokok persediaan barang jadi dan barang dalam proses (Daldjono, 2011; Pandini \& Nurchayati, 2018).

Perhitungan harga pokok produksi merupakan hal yang sangat penting mengingat manfaat informasi harga pokok produksi adalah untuk menentukan harga jual produk. Kesalahan dalam menghitung harga pokok produksi akan menyebabkan kesalahan dalam penentuan harga jual produk.Akibatnya harga jual produk ditetapkan terlalu tinggi 
atau bahkan terlalu rendah (Prastiti, Saifi, \& Z.A, 2016). Harga jual yang terlalu mahal sesungguhnya merupakan citra buruk bagi perusahaan. Bila kondisi ini terjadi dapat mengakibatkan produk yang ditawarkan perusahaan akan sulit bersaing dengan produk sejenis yang ada di pasaran. Sebaliknya jika harga jual produk terlalu rendah, maka akan mangakibatkan laba yang diperoleh perusahaan terlalu rendah.Kondisi ini padapada akhirnya akan berujung fatal pada terjadinya kebangkrutan (Bahri \& Rahmawaty, 2019; Yuliyanti \& Saputra, 2017).

Selain sebagai dasar dalam menentukan harga jual,perhitungan harga pokok produksi bermanfaat untuk mengevaluasi apakah perusahaan sudah berproduksi secara efisien. Berdasarkan informasi biaya produksi, dapat dilakukan identifikasi komponen biaya yang terjadi pemborosan dan dapat segera dilakukan perbaikan, sehingga dapat diperoleh biaya produksi yang lebih murah (Sujarweni, 2016). Informasi harga pokok produksi juga bermanfaat dalam menghitung laba/rugi yang sesungguhnya diperoleh pelaku UMKM, sehingga dapat diketahui perkembangan usaha mereka. Selanjutnya, informasi harga pokok produksi bermanfaat dalam menghitung nilai persediaan, baik persediaan barang jadi maupun barang dalam proses.

Bagi UMKM, laporan Laba/Rugi dan laporan posisi keuangan dapat menjadi dasar dalam mengajukan permohonan pinjaman modal ke lembaga keuangan maupun bank. Bagi lembaga keuangan maupun bank, laporan tersebut menjadi salah satu dasar dalam mengevaluasi kelayakan calon nasabah. Dengan demikian, kemampuan UMKM dalam menyusun laporan harga pokok produksi akan berdampak positif dalam mengatasi permasalahan lain yang umumnya dihadapi para pelaku UMKM, yaitu kesulitan dalam permodalan.

Pengumpulan harga pokok produksi sangat ditentukan oleh cara (jenis) proses produksi yang dilakukan oleh suatu perusahaan. Terdapat dua jenis metode pengumpulan harga pokok produksi,yaitu (1) Metode Harga Pokok Pesanan (job order costing) dan (2) Metode Harga Pokok Proses (process costing) (Daldjono, 2011). Metode harga pokok pesanan merupakan suatu metode pengumpulan biaya produksi untuk menentukan harga pokok produk pada perusahaan yang menghasilkan produk atas dasar pesanan. Tujuan metode ini adalah menentukan harga pokok produk dari setiap pesanan baik harga pokok secara keseluruhan dari tiap-tiap pesanan maupun harga pokok per unit. Dalam metode ini, biaya-biaya produksi dikumpulkan untuk pesanan tertentu dan harga pokok produksi per unit dihitung dengan cara membagi total biaya produksi untuk pesanan tertentu dengan jumlah unit produk dalam pesanan yang bersangkutan. Dalam metode harga pokok pesanan, biaya produksi dikelompokkan ke dalam tiga kategori yaitu biaya bahan langsung, biaya tenaga kerja langsung, dan biaya overhead.

Sementara itu, metode harga pokok proses adalah metode pengumpulan harga pokok produksi yang digunakan oleh perusahaan yang mengolah produknya secara masa. Perhitungan harga pokok produk persatuan dilakukan dengan cara membagi total biaya produksi yang dikeluarkan dengan selama periode tertentu dengan satuan produk yang dihasilkan selama periode yang bersangkutan. Perhitungan dilakukan setiap akhir periode. Menurut metode ini, biaya produksi terdiri atas biaya bahan, biaya tenaga kerja, dan biaya overhead (Herawaty \& Mansur, 2019).

Mencermati uraian di atas betapa pentingnya menentukan harga jual yang tepat bagi keberlangsungan dan kemajuan usaha mikro kecil menengah (UMKM). Hasil komunikasi awal tim pengabdian dengan calon mitra yaitu pelaku UMKM di Kota semarangjuga menunjukkan bahwa mereka belum memiliki pemahaman tentang arti pentingnya menghitung harga pokok produksi dengan benar bagi usaha mereka. Mereka 
tidak menghitung harga pokok produksi sebagai dasar menentukan harga jual karena belum memiliki kemampuan dalam perhitungan harga pokok produksi. Umumnya mereka menentukan harga jual berdasarkan harga pasar. Mereka juga belum mampu menghitung laba rugi dari usaha mereka, serta tidak mengetahui apakah proses produksi sudah dilakukan secara efisien, sehingga mereka tidak dapat mengetahui perkembangan usaha mereka.

Sebagai upaya memberikan solusi atas masalah yang dihadapi calon mitra, tim pengabdian Fakultas Ekonomika dan Bisnis Universitas Stikubank Semarang melakukan pengabdian pendampingan dan pelatihan tentang perhitungan harga pokok produksi beserta pencatatannya. Tujuan yang ingin dicapai dalam kegiatan pengabdian kepada masyarakat Bimbingan Teknis Perhitungan Harga Pokok Produksi bagi Pelaku UMKM di Kota semarang ini adalah (1) memberikan pemahaman kepada para pelaku UMKM tentang arti pentingnya perhitungan harga pokok produksi bagi usaha mereka (2) memberi pelatihan tentang penyusunan harga pokok produksi, baik dari segi konsep maupun praktik, (3) memberi bimbingan teknis proses pencatatan transaksi ke dalam jurnal dan penyusunan laporan laba/Rugi, serta (4) memberi pendampingan di lapangan proses penyusunan harga pokok produksi. Target luaran kegiatan pengabdian masyarakat dengan tema Bimbingan Teknis Perhitungan Harga Pokok Produksi bagi Pelaku UMKM di Kota Semarang ini adalah para pelaku UMKM memahami arti pentingnya penyusunan harga pokok produksi bagi usaha mereka, mampu menyusun laporan perhitungan harga pokok produksi dan melakukan pencatatan transaksidengan benar, serta mengimplementasikan kemampuan tersebut ke dalam usaha mereka.

\section{METODE PELAKSANAAN}

Kegiatan pengabdian ini dilaksanakan dalam waktu 6 (enam) minggu dan pelaksanaan pelatihan adalah 2 (dua) hari, yaitu pada tanggal 28 dan 29 November 2019. Secara keseluruhan rincian waktu pelaksanaan kegiatan adalah sebagai berikut:

1. Persiapan dan komunikasi awal dengan mitra

Pada tahap persiapan dan komunikasi awal ini tim pengabdian Fakultas Ekonomika dan Bisnis Universitas Stikubank melakukan pertemuan dengan tim dari Bank BPR Jateng selaku penyandang dana kegiatan dan perwakilan dari mitra, yang difasilitasi oleh Wakil Rektor Bidang Kerjasama untuk melakukan identifikasi permasalahan yang dihadapi. Tahap pertama ini memerlukan waktusatu minggu.

2. Penyusunan modul pelatihan

Setelah mengetahui permasalahan yang dihadapi mitra, Tim Pengabdian FEB Unisbank menyiapkan solusi. Pada tahap ini dilakukan penyusunan modul dan kasus yang akan digunakan dalam pelatihan selama dua hari. Pelaksanaan tahap ini memerlukan waktu selama dua minggu.

3. Pelatihan

Pengabdian dalam bentuk pelatihan dilaksanakan dalam waktu dua hari.

4. Evaluasi dan Monitoring

Evaluasi dan monitoring kegiatan dilaksanakan melalui dua cara, yaitu evaluasi pada pelatihan hari kedua dan pendampingan selama dua minggu. 
5. Penyusunan laporan

Kegiatan pengabdian kepada masyarakat ini diakhiri dengan penyusunan laporan pengabdian selama satu minggu.

\section{HASIL DAN PEMBAHASAN}

Pengabdian pendampingan penyusunan harga pokok produksi bagi pelaku UMKM di Kota semarang ini dilaksanakan di kampus Universitas Stikubank, Jalan Kendeng V, Bendan Ngisor, Semarang. Berdasarkan hasil komunikasi awal, permasalahan yang dihadapi oleh mitra adalah(1) belum memiliki pemahaman tentang arti pentingnya perhitungan harga pokok produksi bagi usaha mereka, (2) belum memiliki pengetahuan dan kemampuan tentang menghitung harga pokok produksi dan bagaimana mencatat transaksi terkait ke dalam jurnal, (3) tidak menghitung harga pokok produksi dan menentukan harga jual hanya berdasarkan harga pasar, dan (4) tidak mengetahui apakah proses produksi sudah dilakukan secara efisien dan tidak dapat menghitung Laba/Rugi dengan benar dari hasil usaha mereka.

Pemecahan masalah yang dilakukan oleh tim pengabdianadalah memberi pemahaman, pelatihan, dan pendampingan mengenai perhitungan harga pokok produksi dan pencatatan ke dalam jurnal, serta diakhiri dengan penyusunan laporan laba/rugi. Adapun uraian kegiatan yang telah dilakukan yaitu:

\section{Pelaksanaan Kegiatan}

Pelaksanaan kegiatan pengabdian ini terdiri atas pelatihan dan pendampingan, dengan uraian berikut ini.

1. Pelatihan

Pelatihan dilaksanakan selama dua hari. Pada hari pertama pelatihan, para peserta mendapatkan modul pelatihan penyusunan harga pokok produksi yang sudah disiapkan sebelumnya oleh tim pengabdian. Modul perhitungan harga pokok produksi terdiri atas dua materi, yaitu perhitungan harga pokok produksi dengan metode pesanan (job order costing) dan metode harga pokok proses (process costing). Hal ini disesuaikan dengan jenis pabrikasi peserta, yaitu berproduksi berdasarkan pesanan dan berproduksi secara masa.

Pelatihan pada hari pertama dibagi menjadi dua sesi. Sesi pertama diawali dengan pemberian pemahaman tentang arti pentingnya menghitung harga pokok produksi bagi pelaku usaha. Kemudian dilanjutkan dengan memberi materi dalam bentuk konsep perhitungan harga pokok, pencatatanke dalam jurnal dan penyusunan laporan laba/rugi dengan menggunakan metode ceramah dan diakhiri dengan tanya jawab. Pada sesi kedua, para peserta diminta untuk mengerjakan kasus yang sudah disiapkan oleh tim pengabdian. Para peserta mengerjakan kasus perhitungan harga pokok denganbimbingan para anggota tim pengabdian. Kegiatan ini diakhiri dengan diskusi dan tanya jawab.

Pelatihan pada hari kedua diisi dengan praktik nyata perhitungan harga pokok produksi dengan menggunakan data dan informasi dari UMKM peserta yang sudah disiapkan sebelumnya. Jenis proses produksi dua peserta tersebut masing-masing adalah pesanan dan produksi masa, sesuai dengan materi yang sudah dipelajari pada hari pertama pelatihan. Tujuannya adalah agar para peserta mampu mngimplementasikan ke dalam praktik nyata pada usaha mereka masing-masing. 
Kasus dikerjakan dengan panduan dan bimbingan dari anggota tim pengabdian. Sesi ini diakhiri dengan tanya jawab dan diskusi, serta evaluasi tertulis. Kegiatan pada hari pertama dan kedua pelatihan ini diikuti secara serius oleh para peserta. Mereka juga antusias menanyakan hal-hal terkait harga pokok produksi pada usaha mereka. Suasana tersebut terlihat pada pada Gambar 1 dan 2.

2. Pendampingan

Kegiatan pendampingan dilakasanakan setelah dilaksanakannya kegiatan pelatihan penyusunan harga pokok produksi. Tim pengabdian memberikan bentuk pendampingan dalam beberapa metode, antara lain (1) membentuk grup whatshapp (WA) untuk memberi kesempatan kepada peserta pelatihan untuk menanyakan apabila terjadi kesulitan dalam mengklasifikasi biaya, menghitung harga pokok produksi dan melakukan pencatatan di tempat usaha masing-masing. Grup WA ini masih aktif sampai dengan saat ini dan menjadi sarana komunikasi yang cukup efektif, (2)tim pengabdian menyediakan waktu untuk berdiskusi baik melalui email, telephon atau peserta datang ke kampus Fakultas Ekonomika dan Bisnis Unibank Semarang, dan (3) tim pengabdian melakukan kunjungan ke lapangan.

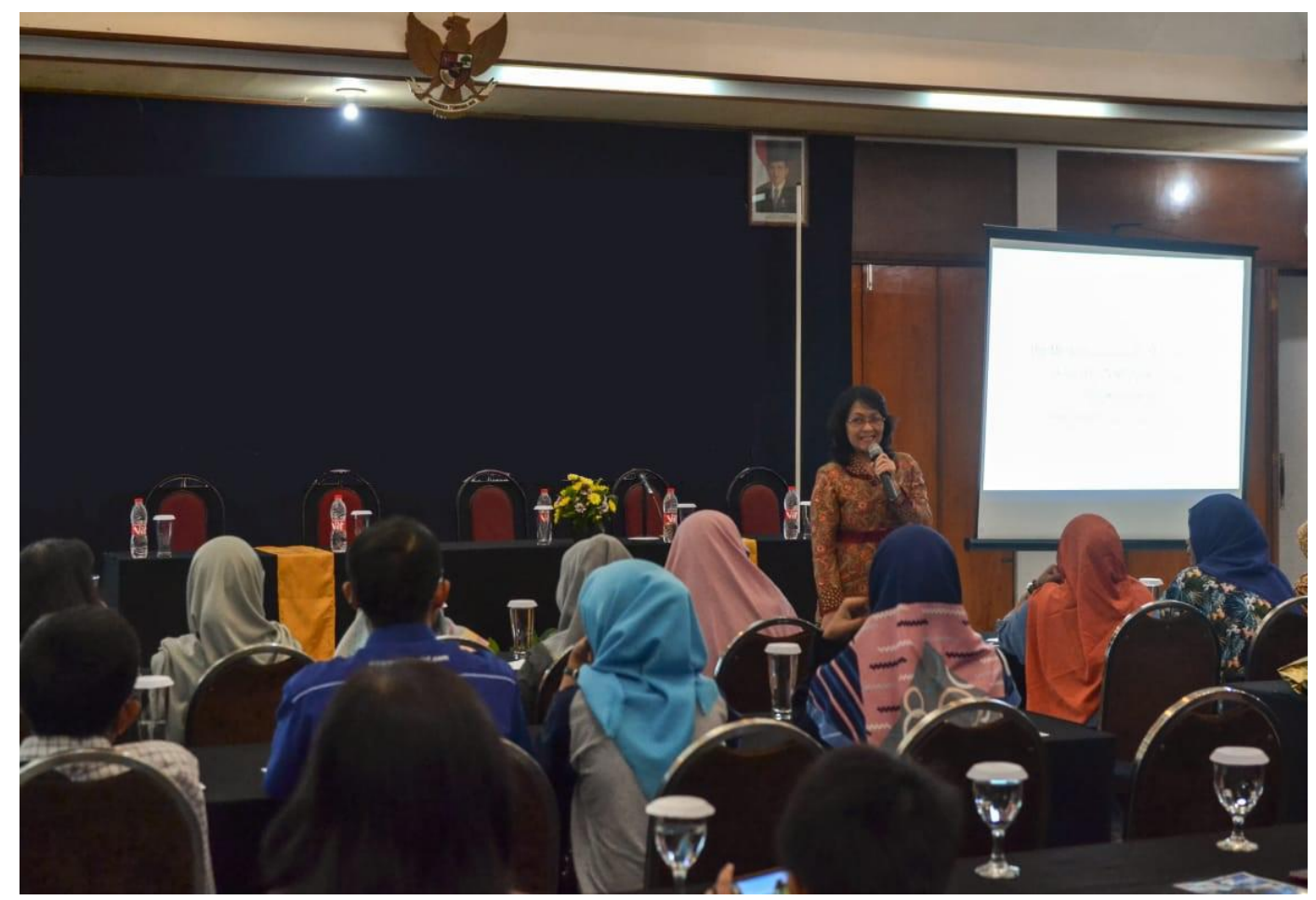

Gambar 1. Suasana Pelatihan Penyusunan Harga Pokok Produksi 


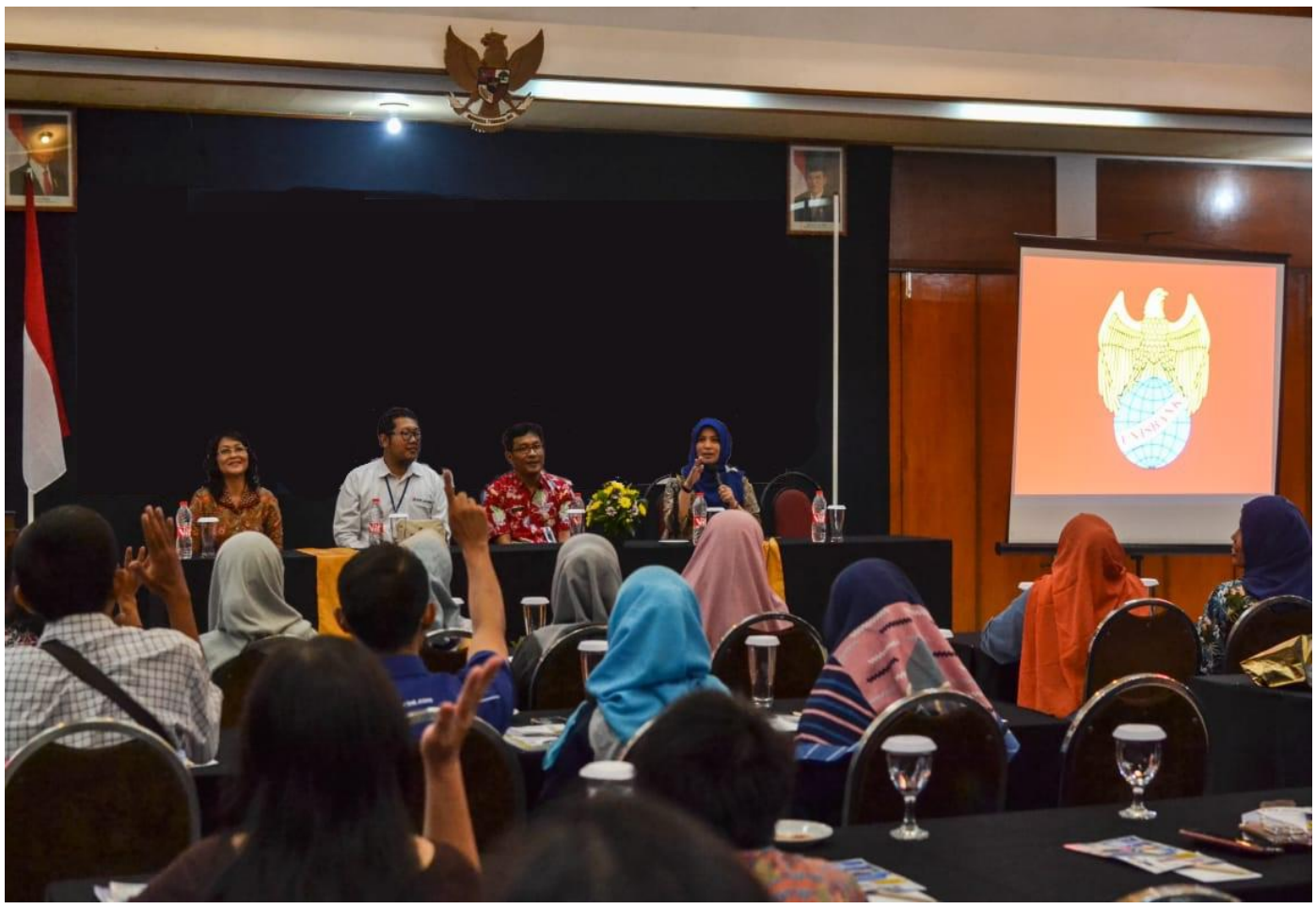

Gambar 2. Sesi Tanya Jawab Penyusunan Harga Pokok Produksi

\section{Evaluasi Kegiatan}

Evaluasi dalam kegiatanini dimaksudkan untuk mengetahui seberapa besar keberhasilan dari kegiatan pengabdian ini. Evaluasi terhadap kegiatan ini dilakukan sebanyak dua kali. Evaluasi pertama dilakukan pada saat pelatihan hari kedua, dimana peserta mengerjakan kasus perhitungan harga pokok berdasarkan pada data dan informasi kegiatan produksi pada dua UMKM yang berproduksi secara pesanan dan produksi masa. Bentuk evaluasi ini dilakukan dengan melihat secara langsung bagaimana peserta mengklasifikasi biaya, menghitung harga pokok produksi dan bagaimana peserta mencatat transaksi ke dalam jurnal, serta menyusun laporan Laba/Rugi. Berdasarkan hasil evaluasi secara keseluruhan, para peserta mampu menyerap lebih dari $70 \%$ materi pelatihan yang diberikan. Berdasarkan jawaban peserta dari pertanyaan tertulis dalam bentuk kuesioner yang diberikan pada akhir sesi pelatihan hari kedua, juga diperoleh informasi bahwa rata-rata peserta merasa puas mengikuti kegiatan ini dan merasa kegiatan ini sangat bermanfaat bagi mereka.

Evaluasi kedua dilakukan setelah peserta mengikuti pelatihan, yaitu pada saat tim pengabdian melakukan pendampingan di lapangan. Evaluasi dilakukan dengan cara membandingkan data dan informasi biaya produksi dengan laporan harga pokok produksi yang telah disusun oleh peserta di tempat usaha masing-masing. Selanjutnya, tim pengabdian melakukan evaluasi terhadap pencatatan transaksi ke dalam jurnal dan laporan Laba/Rugi yang telah mereka susun. Berdasarkan hasil evaluasi, rata-rata peserta kegaitan pengabdian ini sudah mampu menyusun laporan harga pokok produksi, melakukan pencatatan ke dalam jurnal, dan menyusun laporan Laba/Rugi. 


\section{SIMPULAN}

Kegiatan pengabdian dengan pelatihan dan pendampingan perhitungan harga pokok produksi bagi pelaku UMKM di Kota semarangtelah dilaksanakan dengan baik oleh Tim Pengabdian Fakultas Ekonomika dan Bisnis Universitas Stikubank Semarang. Hal ini dibuktikan dengan hasil evaluasi yang menunjukkan 1) peserta mengalami peningkatan pemahaman terhadap arti pentingnya menghitung harga pokok produksi dan melakukan pencatatan ke dalam jurnal 2) peserta mampu menghitung harga pokok produksi, mencatat ke dalam jurnal dan menusun laporan Laba/rugi berdasarkan kasus yang diberikan, 3) peserta mampu mengimplementasikan perhitungan harga pokok produksi, mencatat ke dalam jurnal dan menghitung Laba/Rugi dalam usaha mereka.

Saran yang dapat diberikan mengingat pentingnya penyusunan harga pokok produksi bagi UMKM dengan jenis usaha pabrikan, maka sebaiknya peserta yang dikirim dalam pelatihan ini adalah karyawan yang mempunyai latar belakang bagian yang sesuai dan belum pernah mengikuti pelatihan dengan materi/topik yang sama. Setelah mengikuti kegiatan pelatihan dan pendampingan, sebaiknya peserta mengimplementasikan dalam usaha mereka secara kontinyu agar mereka dapat mengetahui efisien tidaknya usaha mereka, mampu melakukan tindakan koreksi, sehingga usaha mereka berkembang dan maju.

\section{UCAPAN TERIMA KASIH}

Tim Pengabdian Fakultas Ekonomika dan Bisnis Universitas Stikubank Semarang mengucapkan terima kasih kepada semua pihak yang telah membantu kegiatan pengabdian kepada masyarakat ini sehingga terlaksana dengan baik, yaitu: (1) Dr. Elen PuspitaSari, selaku Wakil Rektor Bidang Kerjasama Universitas Stikubank Semarang yang telah memberi kesempatan kepada Tim Pengabdian untuk menjalin kemitraan dengan BPR Jateng dan pelaku UMKM di Kota semarang, (2) Bapak Budiman, SH., Direktur Utama Bank BPR Jateng yang telah memfasilitasi kegiatan pengabdian masyarakat, (3) LPPM Universitas Stikubank Semarang yang telah memberi kesempatan kepada tim pengabdian untuk melaksanakan kegiatan pengabdian ini, (4) Tim dosen dan mahasiswa/iFakultas Ekonomika dan Bisnis Universitas Stikubank Semarang yang telah membantu pelaksanaan kegiatan pengabdian kepada masyarakat ini, serta semua pihak yang telah membantu dalam pelaksanaan kegiatan ini, yang tidak bisa kami sebutkan satu persatu.

\section{DAFTAR PUSTAKA}

Bahri, R., \& Rahmawaty. (2019). Analisis Penentuan Harga Pokok Produksi dalam Menentukan Harga Jual Produk (Studi Empiris pada Umkm Dendeng Sapi di Banda Aceh). Jurnal Ilmiah Mahasiswa Ekonomi Akuntansi (JIMEKA), 4(2), 344358.

Daldjono. (2011). Akuntansi Biaya. Semarang: BPFE Universitas Diponegoro. 
Herawaty, N., \& Mansur, F. (2019). PPM Perhitungan Harga Pokok Produksi Untuk Efisiensi Biaya Produksi Pada Industri Tahu di Kecamatan Jaluko Kabupaten Muaro Jambi. Jurnal Karya Abdi Masyarakat, 3(1), 15-21.

Macpal, B., Morasa, J., \& Tirayoh, V. (2014). Analisis Perhitungan Harga Pokok Penjualan Barang Produksi pada Jepara Meubel di Kota Bitung. Jurnal EMBA, 2(3), 1495-1503.

Maghfirah, M., \& BZ, F. S. (2016). Analisis Perhitungan Harga Pokok Produksi Dengan Penerapan Metode Full Costing pada Umkm Kota Banda Aceh. Jurnal Ilmiah Mahasiswa Ekonomi Akuntansi (JIMEKA), 1(2), 59-70.

Mukhzarudfa, \& Kusumastuti, R. (2019). Praktik Akuntansi Keuangan Usaha Perajin Batik Di Kecamatan Pelayangan, Kota Jambi. Jurnal Karya Abdi Masyarakat, 3(2), 239-248.

Nurlela, \& Rangkuti, C. (2017). Analisis Perbandingan Metode Penentuan Harga Pokok Produksi pada CV. Satu Angin Persada. Jurnal Bisnis Administrasi, 06(01), 6972.

Pandini, R. I., \& Nurchayati. (2018). Evaluasi Penentuan Harga Pokok Produksi CV. Lira Pratama Semarang. Serat Acitya - Jurnal Ilmiah UNTAG Semarang, 7(1), 1-11.

Prabowo, A. A. (2019). Analisis Penentuan Harga Pokok Produksi Berdasarkan Metode Harga Pokok Pesanan (Job Order Costing) pada UD Adi Prima Karsa di Daerah Istimewa Yogyakarta. Jurnal UMKM Dewantara, 2(1), 15-25.

Prastiti, A. E. D., Saifi, M., \& Z.A, Z. (2016). Analisis Penentuan Harga Pokok Produksi dengan Metode Activity Based Costing System (Sistem Abc) (Studi Kasus pada CV. Indah Cemerlang Malang). Jurnal Administrasi Bisnis (JAB), 39(1), 16-23.

Sariwaty, Y., Rahmawati, D., Oktaviani, F., \& Amran, A. (2019). Pengembangan Usaha Mikro Kecil dan Menengah (Umkm) Calief Melalui Implementasi Komunikasi Pemasaran. Jurnal Abdimas BSI, 2(1), 218-224.

Setiadi, P., Saerang, D. P. E., \& Runtu, T. (2014). Perhitungan Harga Pokok Produksi dalam Penentuan Harga Jual pada CV. Minahasa Mantap Perkasa. Jurnal Berkala Ilmiah Efisiensi, 14(2), 70-81.

Sujarweni, V. W. (2016). Implementasi Penentuan Harga Pokok Produksi Untuk Mencapai Laba Optimal (Studi Pada Sentra Ukm Industri Bakpia Di Wilayah Minomartani Sleman Yogyakarta). Jurnal Riset Akuntansi dan Keuangan, 4(3), 1111-1124. doi: 10.17509/jrak.v4i3.4665

Undang-Undang Republik Indonesia Nomor. 20 Tahun 2008 tentang Usaha Mikro, Kecil, Dan Menengah (2008). 
Widyastuti, I., \& Mita, D. (2018). Akuntansi Perhitungan Harga Pokok Penjualan dengan Metode Pesanan untuk Menentukan Harga Jual. Jurnal Moneter, V(1), 74-85.

Wiralestari, Firza, E., \& Mansur, F. (2018). Pelatihan Perhitungan Harga Pokok Produksi dengan Menggunakan Full Costing sebagai Dasar Penentuan Harga Jual Pempek pada Umkm Pempek Masayu 212. Jurnal Karya Abdi Masyarakat, 2(1), 46-52.

Yuliyanti, \& Saputra, R. S. (2017). Analisis Harga Pokok Produksi Roti Berdasarkan Metode Full Costing dan Variable Costing. Jurnal Online Insan Akuntan, 2(2), $229-236$. 